\title{
THE ART OF BEING INTERESTING: AN INTERVIEW WITH BARRY HANNAH
}

\section{Jamie S. Dycus}

Barry Hannah is author of numerous books of fiction, including the novel Geronimo Rex, which won the William Faulkner Prize and was nominated for the National Book Award, and the story collection Airships, which established Hannah as a master of the short story. Hannah also is the recipient of an award for fiction from the American Academy of Arts and Letters and of a Guggenheim Fellowship. A faculty member at the University of Mississippi, Hannah has taught creative writing for over thirty years and is presently at the University of Iowa Writers' Workshop as a Writer in Residence. In the following interview, Hannah talks with Jamie Dycus about writing, risk-taking, and real life.

\section{I thought we might start by talking about what you think of Iowa.}

I taught here back in 1981. It was good then, and it's good now. I think there are too many MFA programs, but Iowa remains distinguished, and-I've been asked this by several students-does it do any good, is it worthwhile? For me it was. I mean, I didn't learn enough in college, and I needed an MFA very much for the discipline and the time. I don't know a better place than Iowa. It's a process where, if I were a student, often you can't see things happening. It's probably not as pleasant to be a student sometimes as it is to be a teacher, because a teacher sees so much talent. There are very few dilettantes. People are serious. And that's the one requirement. They have talent and they're serious. I'm a better teacher at that level than any other level. But there's not-the extreme dedication to, say, fine arts, is more eccentric than it was when I was in school in the sixties. It used to be the thing a man or woman could do with great respect. It's just more casual now, a much more businesslike and conservative atmosphere, everywhere. But I feel privileged to teach at Iowa. I'm certain I'm at the best writing school in the world, even with its flaws. And my favorite time of all the week is when I teach, and reading the kids. It's still a beautiful process. I hope I can add something to it. 
Let's go back'for a minute to what you said about the way that people's attitudes toward writing are changing. Do you have the sense that serious fiction is in a depression right now?

Yes, and that's for two reasons. I don't think they're expecting enough from novels. There are not enough people who blow you out of your seat. I think there's high competency, and the novel is very disappointing now, and there's also been a recent, ten years, where case histories sufficed for novels, diseases, family dysfunction, what's wrong with me, what's my disease, which is all right, but it's so close to journalism and confession, that often it's rather artless, and almost inevitably charged with some self-pity. Awareness, sometimes, just passes for a subject, too often. I like big tales. As I Lay Dying is one of my favorite books. Big things happen to little people. Or crises. Dramatic gestures where people can say something or do something, even if futile. There's a lot more of just getting through an ordinary day as a young woman, and being normally sensitive, that passes for literature. I don't know why it's read; I don't know why it's bought. It always astounds me that people aren't going for more in their books.

\section{It's just not interesting to you.}

No. I've been off fiction. I read more biography and poetry now. Just for inspiration. Great biographies are just as - they're better than most fiction. And the poetry is where I-I love the sentence. I love things to happen. A writer who puts life on the page, every page, is my kind of writer. I don't care much about plot. Just a shape, not even real structure. I want somebody to give me real life, put me in another world, in real life, per page, that's what I want, and poets can do it, the best poets can do it beautifully.

But now you say on the one hand that you're disappointed with the novels that you've been reading because they're too prosaic. It's just ordinary boring things that happen -

They're expository; they're chattery -

You want real life.

Yeah.

How does a novelist balance between not being too boring, but at the same time being real? I mean, isn't a lot of real life boring?

Yeah, it is, but I don't think you should duplicate it. I think two pages will suffice. And I think it's like Hitchcock said, art is life with the boring parts cut out. I mean, it's true that our own lives will only give up about three plots. There 
are three-you know, you get married, you die, you get in trouble. But you've got to know what to forget, and what's important. I'm with those who say that all good writing is about life and death. Sometimes boredom is close to death, and it's an important subject. So, a day in the life-I have no-there's no reason for me to be interested in many of these stories about waitresses, or-not because they're low on the economic scale, just there's not very interesting waitresses. I would love a passionate waitress with some dimension. But you can take democracy too far in writing. Everybody's not interesting. That's the point I'm making. I'm not, most of the time. Just rarely. And I would like to write about those times when I was most interesting. Or at least, most vulnerable, you know.

You say that for you, life and death are the things that are the most interesting, or the best subjects to write about. Do you ever get frightened by what you consider to be interesting subject matter? Isn't a lot of the best subject matter terrifying?

There's a little bit of terror to almost all the good stuff I recall in literature, a little bit of terror, like Heart of Darkness. I love the ghost story. I love to go after mysteries. I think all the best stories I have ever read are very close to ghost stories. I have no interest, by the way, in Poltergeist. But I am interested in the mysterious $\mathrm{X}$, the big force behind something perceived. We're usually not privy to too many of those things ourselves. But our friends have lived them. Of course I grew up in the Vietnam era. My classmates fought the war, came back with their tales-it still works on the heads of people my age, because it was a fantastic zone, that some of the veterans can't even acknowledge happened nowadays, you know? But there are other places you've been that are-Denis Johnson examines these things-zones of irreality that had not only horror, but some sweetness. The writer ought to go into these other zones and come back like a spy, and tell us something exciting. And move us. And sometimes disgust us. There's not enough of that now.

Do you ever get into the other zone and wish that you weren't there? Or wish that you could run back? Have you ever gotten into a story, and then decided not to proceed, not to finish that story, or not to write that story?

Not because it was too terrifying. I've never scared myself that deeply. Maybe if I were a better writer- (Laughs). I want to go into those zones, though. I don't invoke them, like some phony who just rides a bicycle in a storm, just for a poem. Things happen normally. Your pets die, your friends die, my God, these are things that are horrible to me. And they cut you down, and you're not the same. You ought to write about these things. You find-when you're forty, you find out you're going to die, finally, and so everything becomes a little more urgent. I think writers, by the way, know they're going to die, young, and that they'd better get things down. They have more urgency. I think the others don't 
really think they're going to die, but the writer knows he's going to die. He needs to get something down. He doesn't want to be just erased, you know? So I don't think the number of urgent things is infinite. And I think white people, white writers now, have a terrible time being interesting. Because they're almost talked out.

\section{Could you explain that a little bit?}

I just can't get interested in suburban problems too much more. Adultery, alcoholism, failed stock market—John Cheever was wonderful at that kind of stuff. But I just don't - I think that we have chatted, and examined ourselves too psychologically. We don't have much to compete with when we get up in the morning. The subjects, when you have plenty of comforts, are extinguished, if you don't watch it. There should be more adventure. More risk. And there's less risk, I think, now, and there's more seeking economic certainty among the young than I've witnessed in a long time. But it's not that all blacks are interesting, or that Indians are just interesting for being Indians; it's just that their tales have not been so exhaustively told. And I love white people. I'm one of them. But we've got to find important things to write about, you know? Because we're not all-television teaches us that everybody is interesting. Blah, blah, blah. Everybody gets, you know, fifteen seconds. But they're not. We've got to find the most interesting things. That's why I go for entire lives in my short stories. I don't go for just small moments, the epiphanic moments. I like to see a life in a short story. I think that's the way I've almost always worked. Big things that happen in my life, his life.

Do you think that important writing, then, is becoming the province of just one group of people? Does that mean that it's more likely, if a person is white, that they're not going to have anything to say that's worth hearing?

Yes. Yeah, because we have dominated so long in America. Our subjectsthere will always be interesting books about all races, but a white guy has just been too self-conscious for too long. I mean, when you have to-I think people are forced into little corners of interest, because everything else has been said, they feel. The sense of adventure-space itself does not interest me like it did. Space has become kind of a strato-bus, I mean, it's not some woolly trip to Mars with a good-looking blonde Ph.D., in a rickety ship. It's just becoming so regular. So I think you've got to be zealous. I think people save themselves by waking up to their own worlds, though. I don't think you need to get in a diving outfit and just go down to see something hideous. They've got to wake up to something that's very vital, that we've missed.

What about waking up to other people's worlds? What about people who go across those lines and write about people who are different?

Absolutely. Right. Absolutely. I think that it should be free travel. It's always 
wonderful to see the outsider's point of view. The outsider can often cover the town better than you, who live there. He knows more, can see more, whereas the person in it is rather blinded by habit.

Isn't there a problem of authority there, though? For example, if you're a white person writing about black people because their story has not been told, don't you run into the problem of you don't necessarily have the right to tell their story?

Yes. And I wouldn't. I may write about a black person as he appears to me. I wouldn't try to do the inside of a black person. That's rather presumptuous. However, it's said that people who-like women-who live in male dominated societies, write much better about men, than men write about women. Because they have known, they've had to contend with a dominant force. So because of the dominant culture, blacks may be able to write about whites better than whites about blacks. It would be tough for me to write about the inside of an Indian, though, as much as I've admired them. My first novel, Geronimo Rex, is about a boy who worships Geronimo. But, yeah, I don't feel the authority to do an extensive work about black folks. Also, white folks, when they write up blacks, tend to sentimentalize them, even when they purport to love them-they write sentimentally, with atrocious nostalgia, sometimes, because you see it happen around Oxford, where we live-the people who really love the blues are white people. (Laughs.) Because they go out seeking - this is real, this is earnest, this is poor. This smells a little bit. But it's there, baby. You know, all I got's a Volvo, and these are the real guys. So, you know that kind of panic for another life, because yours is empty? There's that tendency too.

How does being in Mississippi play into that? Is there more opportunity for genuine real life in a place like Mississippi? Not necessarily tourist real life, but like you've just described it.

Well, the real life-I've never thought that a university cuts you off from real life. Oxford is fairly cosmopolitan, for Mississippi. You see Indians, and many Asians, along with about ten percent blacks on campus, but blacks and whites have lived together a long time in Mississippi. We've shared music, preachers, religion, so that everybody's a little bit black, that's white. Everybody almost. There's no-it's a shame that there's not more dialogue, because there's so much common experience. Realer? It is to me, because I don't have to explain as much. Fishing - the basic things-fishing, sport, religion, have stayed constant since I've been born. So there's just kind of an acknowledged field, what people do, where not much conversation is required, and it's kind of nice, just easy.

But is it closer to -

Passion? 
Yeah. We've been talking about risk, and fear. Is it closer to those real, important things?

I think probably there's a sense that single people can effect change in the South, more than in the Midwest and East. Maybe because of just the lower population. Writing, and a voice, is still respected. A good tale is respected, although you don't get too many old uncles spinning them on the front porch. Men don't even tell extensive jokes anymore there. I've noticed they've gotten shorter and filthier. They used to be kind of long, you had to listen, but they've become just kind of one-line poppers, rather than narratives. I feel just more native, and realer, when I'm down there. Seems like individuals matter a bit more. Even the gossip's better.

Why do you think that is? What's the source of all that?

Boredom. (Laughs.) Mixture of cultures. It's the pretentious rednecks that I love. The rich rednecks are interesting. It's a whole new class, and it's just-it's not Texas, it's just-watching a guy try to have good taste is enormously funny to me sometimes, and I'm no snob. I didn't inherit great taste. I was uppermiddle class, for what it means, but I love these people as well as laugh at them. And it's also a structured society, more. You know, classes are instantly known. By preference for trucks. And classes have pride. There are people who look down on me because I don't have a truck. You know? So it's easier for writers in the South because there's a distinct culture.

\section{Have you always been writing?}

Well, seriously since I was a sophomore in college, but I told tales in the third grade. But I didn't know I loved it so much until I was about twenty. I'd written a little bad poetry, imitation of the Beats, but I really started loving tales when I was a junior or senior, and then I did an MFA at Arkansas. And I grew up with an inferiority complex about being from Mississippi, because you know, it had the civil rights horrors, it was reviled, with good reason. But also it made you fight harder, to be known as not a dummy and no racist. It gave you something to shoot for. So I think that negative perception helped me. I wanted to shine, and be uncommon in some way. But I love the story best of all, and especially through Hemingway, and Joyce, and Faulkner, later with Henry Miller. Flannery O'Connor I discovered in grad school. That was a real find. Then I found out she'd come through here. You know, I keep looking for these wild people, like Flannery O'Connor, and they're hard to find. Yeah, anywhere. Ole Miss, here. People who just sort of stomp out with some vision. They don't know where they got it; they're just convinced of certain things, and there's a wholeness, sort of a godstruck view of life that's not been taught. You know, I'm looking for that, always, in my students. 
Would you place yourself in that category?

I don't know. I hope I had some of that when I started writing, and I try, actually, to forget all the books when I write, now. I'm afraid-I envy my students, because they can do some things that forty-five-year-old people and up can't do anymore. The forty-five-year-old people have gotten too damn sophisticated. They've read too much. Everything's a filter. Whereas the kids here are finding their own voices. That's going to be their stuff. I had some stuff at twenty-three I wish I still had. Yeah, the original stuff, you know. I mean, you're so hungry, you're so hungry. I'm less good at just making peace than I was at discovering the world.

Was there a moment when you knew that you wanted to do writing forever, instead of doing something else?

Yeah, at Arkansas. I didn't know I'd do this much teaching. I wanted to be a best-seller, and support myself after I'd taught just a little, but it didn't happen. You know, my maximum sales are forty thousand, and that's paperback andso listen, I'm not a lot better off than a lot of folks, but I've also had three kids, put in college, and-the amount of teaching I do has worked out beautifully, because I don't teach too much. I'm not burned out. I still believe in it. I've seen results. So I don't have any regrets. I had just expected to live in a large house on my books. That's the only difference in schedule. It could still happen. (Laughs.)

In the story "The Ice Storm," there's a line from the first-person writer-narrator, in which he says, "I was writing very well, almost under a miracle burst." And there's not really any explanation or development of that line, but that seemed like an important line to that guy's, that character's - what does that mean? And is that something in your experience?

That was the creation of Bats Out of Hell, when I just couldn't quit writing. It was right after my father's death, and my mother was slowly dying too, as I recall I say in the story. Something just came along where I was just getting up at about five, four-thirty, five in the morning, just full of zeal, and I couldn't quit writing stories for a year and a half. I just haven't had that in quite a long time, not since my first novel. I've written more deliberately, and more slowly. But this was one of those times when I just felt driven, and happy, happy. I loved my father, and it was not, you know, a release of his presence, it was just - maybe I just figured now look, your father's gone ahead and died, and it's up to you, you've got to be good. You're the captain now. So maybe I responded to that. And I was also back at my old home, which probably-you know, I'm a nostalgist, and I could just feel my stamping grounds around there.

Are you happy when you write? 
Yes. I'm happy when I write well. I can always tell when I don't have a real story in me, it's going very slowly, and it's rather clerkish.

But you just press on through that.

I press on. I've made some decent stories that way. But when it's really good, it's close to ecstacy. Yeah. It sure is. 